\title{
Tindak Tutur Ilokusioner Ekspresif Plesetan Nama Kota di Jawa Tengah: Kajian Pragmatik
}

\author{
Hari Kusmanto \\ Program Studi Pendidikan Bahasa dan Sastra Indonesia, Universitas Muhammadiyah Surakarta, Indonesia \\ E-mail: harikusmanto8@gmail.com
}

\begin{abstract}
This study aims to explore the forms of expressive speech acts that play on the names of cities in Central Java. The data in this study is a play on the names of the cities in Central Java that are expressively valued. The data source in this study is a play on the names of Cities in Central Java. Data collection in this study uses the documentation method, and see continued recording techniques. Analysis of the data in this study uses the intralingual equivalent method. The results of this study indicate that the play on the names of Cities in Central Java is expressed with expressions of sadness, happiness, disappointment, complaining, convincing, hope, forgiveness, praise, and criticism. The most widely used expressive speech act is sadness expression. This shows that many speakers experience a sad experience.
\end{abstract}

Keywords: expressive; playful; pragmatic speech acts

\section{PENDAHULUAN}

Tindak tutur pada wacana plesetan nama-nama Kota di Jawa Tengah menarik untuk dikaji lebih lanjut karena hal ini tidak hanya berkaitan dengan aspek kebahasaan melainkan juga berkaitan dengan aspek psikologis. Studi ini dilatarbelakangi banyaknya fenomena plesetan nama-nama Kota di Indonesia kkhususnya Jawa Tengah. Selain itu, tindak tutur ekspresif yang ditampilkan dalam plesetan nama-nama kota sebagai cermin psikologis penutur. Penutur plesetan nama Kota di Jawa Tengah banyak diantaranya adalah generasi muda. Hal ini menunjukkan plesetan nama-nama Kota di Jawa Tengah sebagi ekspresi kreatifitas pemuda pada saat ini.

Tindak tutur sebagai salah satu bentuk komunikasi antara penutur dan mitra tutur adalah tindakan berbahasa yang memiliki daya untuk menginformasikan, memerintah ataupun mengekspresikan psikologis penutur. Tindak tutur merupakan suatu bentuk tuturan yang bersifat informatif, fungsional, dan memiliki akibat tertentu (Kusmanto, 2019). Tindak tutur merupakan tindakan-tindakan yang ditampilkan melalui tindak tutur (Yule, 2014). Tindak tutur memiliki aspek-aspek situasi tutur yang meliputi penutur dan lawan tutur, konteks tuturan dan tujuan tuturan (Wijana \& Rohmadi, 2009).

Berdasarkan pengertian tersebut di atas tindak tutur dapat diklasifikasikan menjadin tiga jenis. Austin menyatakan tindak tutur dapat dibagi menjadi tiga jenis yang meliputi: (1) tindak tutur lokusi adalah tindak tutur yang hanya sekadar memberikan informasi kepada mitra tutur, (2) tindak tutur ilokusi adalah tindak tutur yang mengandung maksud tertentu, dan (3) tindak tutur perlokusi adalah tindak tutur yang bertujuan untuk mempengaruhi mitra tutur (Ekawati, 2017).

Tindak tutur ekspresif termasuk ke dalam tindak tutur perlokusi. Tindak tutur ekspresif adalah tindak tutur yang dilakukan dengan tujuan menilai atau mengevaluasi sesuatu hal yang disebutkan pada tuturan (Manaf, 2011). Hal yang berbeda dikemukakan Yule bahwa tindak tutur ekspresif mencerminkan pernyataan-pernyataan psikologis dan dapat direalisasikan dengan pernyataan kegembiraan, kesulitan, kesukaan, kebencian, kesenangan, atau kesengsesaraan.

Wujud tindak tutur ekspresif meliputi: (1) berterima kasih; (2) memberi selamat; (3) meminta maaf; (4) menyalahkan; (5) memuji; (6) belasungkawa; (7) menyambut; (8) mengkritik; (9) mengeluh; dan (10) menyanjung (Defina, 2018).

Berdasarkkan uraian yang telah disajikan di atas peneliti tertarik untuk mengkaji lebih lanjut bentuk-bentuk tindak tutur ekspresif wacana plesetan nama-nama Kota di Jawa Tengah. Fokus penelitian ini adalah bentuk tindak tutur ekspresif pada wacana plesetan nama-nama Kota di Jawa Tengah.

\section{METODE}

Metode studi ini adalah deskriptif kualitatif. Metode deskriptif kualitatif dalam studi ini bertujuan menghasilkan deksripsi data berupa bentuk-bentuk tindak tutur ekspresif pada wacana plesetan nama Kota di Jawa Tengah. Data dalam studi ini adalah plesetan-plesetan nama Kota di Jawa Tengah yang memiliki nilai ekspresif. Sumber data dalam studi ini adalah plesetan nama-nama Kota di Jawa Tengah. 
Pengumpulan data dalam studi ini menggunakan metode dokumentasi dan simak dilanjutkan teknik simak bebas libat cakap. Dokumentasi yang dimaksud dalam studi ini adalah video youtube yang menyajikan plestan nama-nama kota di Jawa Tengah yang. Metode simak dilakukan oleh peneliti dengan cara penyimakan, selanjutnya dilanjutkan dengan pencatatan data pada kartu data sesuai dengan bentuk-bentuk tindak tutur ekspresif.

Analisis data dalam studi ini menggunakan metode padan intralngual (Mahsun, 2014) dan padan referensial (Sudaryanto, 2015). Metode padan intralingual dan padan refernsial dalam studi ini digunakan untuk mengidentifikasi bentuk-bentuk tindak tutur ekspresif pada plesetan nama Kota di Jawa Tengah.

\section{HASIL DAN PEMBAHASAN}

Berdasarkan data yang diperoleh ditemukan nama-nama Kota di Jawa Tengah diplestakan. Berikut nama-nama Kota yang diplesestakan diantaranya adalah (1) Pemalang, (2) Batang, (3) Ambarawa, (4) Klaten, (5) Jepara, (6) Blora, (7) Purbalingga, (8) Sragen, (9) Kudus, (10) Semarang (11) Tegal, (12) Surakarta, (13) Demak, (14) Salatiga, (15) Banjarnegera, (16) Banyumas, (17) Wonogiri, (18) Rembang, (19) Purworejo, (20) Kendal, (21) Magelang, (22) Slawi, (23) Boyolali, (24) Pekalongan, (25) Mungkid, (26) Grobokan, (27) Purwodadi, (28) Karanganyar, (29) Brebes, (30) Cilacap, (31) Kajen, (32) Temanggung, (33) Pati, dan (34) Kebumen. Berdasarkan nama Kota yang diplesetkan ditemukan wujud tindak tutur ekspresif yang paling dominan adalah eskpresi sedih dan bahagia. Berikut ini tabel persentase tindak tutur ekspresif plesetan nama Kota di Jawa Tengah.

Tabel.1

Persentase wujud tindak tutur eskpresif

\begin{tabular}{ccc}
\multicolumn{3}{c}{ Persentase wujud tindak tutur eskpresif } \\
\hline \multirow{2}{*}{ No } & Wujud Tindak Tutur Ekspresif \\
\cline { 2 - 3 } & Tindak tutur Ekpresif & persentase \\
\hline 1 & Sedih & $35 \%$ \\
2 & Bahagia & $23 \%$ \\
3 & Kecewa & $9 \%$ \\
4 & Mengeluh & $9 \%$ \\
5 & Meyakinkan & $6 \%$ \\
6 & Pengharapan & $6 \%$ \\
7 & Memberi maaf & $3 \%$ \\
8 & Memuji & $3 \%$ \\
9 & Mengkritik & $6 \%$ \\
& Jumlah & $100 \%$ \\
\hline
\end{tabular}

Berdasarkan tabel 1 yang disajikan di atas menunjukkan terdapat 9 wujud tindak tutur ekspresif pada plesetan nama Kota di Jawa Tengah. Hal tersebut menunjukkan penutur menggunakan daya psikologisnya dalam menyampaikan tuturannya. Berikut disajikan pembahasan wujud tindak tutur eskpresif plesetan nama Kota di Jawa Tengah.

a. Tindak Tutur Ekspresif bersedih
Tindak tutur ekspresif bersedih merupakan tindak tutur yang bermaksud menyampaikan rasa sedih yang dialami oleh mitra tutur. Eskpresi sedih sebagai cermin yang menunjukkan emosi seseorang mengenai baik dan buruk (Hendrastuti, 2017). Subtindak tutur bersedih ini paling banyak ditemukan pada plesetan nama-nama Kota di Jawa Tengah. Berikut ini plesetan berekspresi sedih.

(1) Pemalang: percuma bilang sayang, jika kamu malah menghilang.

Plesetan pada data (1) di atas merupakan plesetan Kota pemalang yang memiliki nilai ekpresi kesedihan. Hal ini terlihat pada Kota pemalang yang diplesetkan menjadi percuma bilang sayang, jika kamu malah menghilang. Tuturan tersebut menunjukkan kesedihan yang disebabkan karena rasa sayang yang disampaikan kepada orang yang disayanginya tapi malah menghilang. Eskpresi kesedihan berhubungan dengan rasa bahasa (Herniti et.al, 2016). Nilai rasa bahasa pada data di atas adalah sedih yang disebabkan karena rasa cinta yang disampaikan penutur tidak mendapatkan respon yang baik oleh mitra tutur. Berikut ini disajikan tindak tutur eskpresif sedih yang lainnya.

(2) "Purbalingga: pura-pura bahagia eling mantan sing wis berkeluarga"

(Pura-pura bahagia mengingat mantan kekasih yang sudah berkeluarga)

Tuturan pada data (2) di atas merupakan plesetan Kota di Jawa Tengah, yakni Purbalingga. Nama Kota Purbalingga pada data di atas diplesetkan menjadi pura-pura bahagia eling mantan sing wis berkeluarga. Tuturan tersebut merupakan tindak tutur ekspresif bersedih hal tersebut terlihat dengan kata pura-pura bahagia.

Tuturan plesetan tersebut merupakan wujud tindak tutur ekspresif bersedih. Ekspresi bersedih merupakan bentuk simpati dan empati (Osman \& Wahab, 2018). Ekpresi kesedihan pada data di atas direalisasikan dengan ungkapan Pura-pura bahagia mengingat mantan kekasih yang sudah berkeluarga. Tuturan tersebut menunjukkan kesedihan penutur yang bersedih karena ditinggal menikah kekasihnya. Kegagalan dalam menjalin hubungan memang terkadang berakhir pada kekecewaan dan kesedihan.

\section{b. Tindak Tutur Ekspresif Bahagia}

Tindak tutur ekspresif bahagia merupakan tindak tutur yang memiliki makna kebagiaan yang dialami oleh penutur dalam tuturannya. Subtindak tutur bahagia pada plesetan nama Kota di Jawa Tengah cukup banyak, yakni dengan persentase 23\%. Berikut ini contoh-contoh plesetan nama Kota di Jawa Tengah yang memiliki nilai ekpresif bahagia.

\section{(3) Batang: baru denganmu aku merasa tenang}

Tuturan pada data (3) di atas merupakan plesetan nama Kota Batang. Kota Batang pada data di atas diplesetkan menjadi baru denganmu aku merasa tenang. Tuturan pada data tersebut di atas termasuk ke dalam tindak tutur ekspresif bahagia atau gembira. Hal tersebut terlihat melalui tuturan di atas yang bermakna bahwa penutur akan merasa tenang, 
damai, bahagia apabila dengan seseorang yang dimaksud oleh penutur.

Seseorang yang dimaksud oleh penutur pada tuturan data di atas tentunya orang yang dapat membahagiakan penutur. Pada konteks penutur yang masih muda yang dimaksud bahagia bersamamu adalah kekasih atau pacar penutur. Ekpresi kebahagian tersebut menunjukkan penutur sangat memncintai kekasihnya. Berikut ini disajikan satu data lagi tindak tutur ekspresif kebahagiaan.

(4) Semarang: senyum manismu membuat hatiku terang

Tuturan pada data (4) di atas plesetan yang memmiliki nilai ekpresif bahagia. Hal ini terlihat pada tuturan senyum manismu membuat hatiku terang. Hati yang terang menunjukkan kebahagian yang dialami oleh penutur. Adapun hati yang gelap adalah ekspresif kesedihan.

Penutur pada tuturan tersebut di atas bahagia karena mendapatkan senyuman dari orang lain. Orang lain dalam tuturan tersebut tentu bukan sembarang orang, maksudnya ialah orang spesial seperti kekasih sehingga hanya dengan senyuman saja penutur sudah sangat bahagia.

\section{c. Tindak Tutur Ekspresif Kecewa}

Tindak tutur ekspresif kecewa merupakan tindak tutur yang memiliki makna rasa kekecewaan yang dialami oleh penutur. Ekspresi kecewa merupakan salah satu bentuk tuturan yang menunjukkan kemarahan penutur (Sholihatin, 2013). Tindak tutur ekspresif kekewa pada plesetan nama Kota di Jawa Tengah terdapat 9\%. Berikut ini tuturan plesetan nama Kota di Jawa Tengah berekspresi kekecewaan.

(5) Banjarnegera: banyak janjimu kudengar namun gagal dan buatku jera.

Tuturan pada data tersebut di atas plesetan Kota Banjarnegara. Kota Banjarnegara pada data di atas diplesetkan menjadi eskpresi kekecewaan penutur. Ekpresi kekewaan tersebut disebabkan karena mitra tutur melanggar maksim kualitas, yakni dengan mengingkari janji-janji yang telah dibuat (Devi \& Qomaruddin, 2017). Ekspresi kekecewaaan pada data di atas direalisasikan dengan cara memplesetkan Kota banjarnegara menjadi banyak janjimu kudengar namun gagal dan buatku jera.

Ekspresi kekecewaan pada data di atas disebabkan karena janji yang disampaikan mitra tutur banyak diingkari. Menepati janji merupakan strategi untuk membuat mitra tutur senang dan menghindarkan dari kekecewaan (Yayuk, 2016). Pemberi janji adalah memberikan pengharapan kepada orang yang menerima janji maka apabila berjanji seharusnya ditepati. Janji yang tidak ditepati akan menjadikan kekecewaan bagi penerima janji. Berdasarkan hal tersebut tuturan pada data di atas dapat dogolongkan sebagai tindak tutur ekspresif kekecewaan.

\section{d. Tindak Tutur Ekpresif Mengeluh}

Tindak tutur ekpresif mengeluh merupakan tuturan yang memiliki makna mengeluh yang dialami oleh penutur. Tindak tutur ekspresi mengeluh terjadi karena rasa tidak puas atau tidak sesuai dengan keinginan diri (Rahayu, Siti, 2012).
Ekpresi mengeluh dapat direalisasikan dengan cara mengeluh karena capek, mengeluh karena disakiti, mengeluh karena bosan, dan sebagainya. Tindak tutur ekpresif plesetan nama Kota di Jawa Tengah direalisasikan dengan mengeluh karena hutang belum dibayar. Berikut ini tindak tutur mengeluh pada plesetan nama Kota di Jawa Tengah.

(6) Karanganyar: kangen marang kowe sing utang durung dibayar

Tindak tutur pada data (6) di atas merupakan plesetan nama Kota Karanganyar. Kota karangnyar pada data di atas diplesetkan menjadi kangen marang kowe sing utang durung dibayar yang memiliki makna mengeluh. Ekpresi mengeluh terkadang juga bermanfaat asalkan sesuai dengan tempat dan waktu yang tepat (Vida, 2011). Namun sebaliknya tuturan mengeluh apabila tidak sesuai dengan konteks yang terjadi adalah tejadinya penyimpangan maksim kedermawanan atau ketidaksantunan (Febriadina et.al, 2018). Ekspresi mengeluh pada data di atas disebabkan karena hutang yang belum dibayar.

Tuturan kangen pada data di atas memiliki ekpresi kerinduan, namun apabila dilihat tuturan secara lengkap memiliki makna ekspresi mengeluh. Ekspresi mengeluh bertujuan untuk mendapatkan simpati dari mitra tutur (Hartati, 2018). Selain bertujuan untuk meminta simpati mitra tutur mengeluh juga disebabkan karena banyak masalah yang harus diselesaikan penutur (Syaifudin, 2017). Kangen pada tuturan data di atas tidak merujuk kepada seseorang, melainkan lebih kepada hutang yang belum dibayar oleh mitra tutur. Berdasakan hal tersebut dapat disimpulkan tuturan tersebut memiliki makna ekspresif mengeluh.

\section{e. Tindak Tutur Ekpresif Meyakinkan}

Tindak tutur ekpresif menyakinkan merupakan tuturan yang berusaha memberikan keyakinan kepada diri penutur dan mitra tutur. Tujuan tindak tutur meyakinkan adalah untuk memperoleh persetujuan mitra tutur (Kasenda, 2018). Tindak tutur ekpresif plesetan nama Kota di Jawa Tengah direalisasikan dengan tujuan meyakinkan mitra tutur mengenai perasaan hati penutur. Berikut ini plesetan nama Kota di Jawa Tengah.

\section{(7) Jepara: jelas perasaanku padamu tanpa pura-pura}

Tindak tutur ekspresif pada data (7) di atas merupakan tindak tutur ekspresif meyakinkan penutur dan mitra tutur. Tindak tutur ekspresif menyakinkan direalisasikan pada plesetan nama Kota Jepara. Kota Jepara pada tuturan data di atas diplesetkan menjadi jelas perasaanku padamu tanpa purapura.

Tindak tutur meyakinkan biasanya direalisaikan melalui tuturan persuasif (Nirmala, 2015). Penutur pada tuturan tersebut berusaha meyakinkan mitra tutur bahwa penutur memang benar-benar mencintai mitra tutur. Hal tersebut dituturkan dengan ungkapan menjadi jelas perasaanku padamu tanpa pura-pura.

f. Tindak Tutur Ekpresif Pengharapan 
Tindak tutur ekspresif pengharapan merupakan tindak tutur yang memiliki makna pengharapan penutur. Tindak tutur ekspresif pengharapan pada plesetan nama Kota di Jawa Tengah direalisasikan dengan pengharapan bisa menjalin hubungan dengan mitra tutur. Berikut ini tindak tutur ekspresif pengharapan pada plesetan nama Kota di Jawa Tengah.

(8) Kajen: kepengen mbi kowe jejeran dadi manten (ingin bersama kamu bersanding menjadi pengantin)

Tindak tutur ekspresif pengharapan pada data (8) di atas merupakan plesetan nama Kota Kajen. Kota Kajen pada data di atas diplesetkan menjadi kepengen mbi kowe jejeran dadi manten. Tuturan tersebut memiliki makna pengharapan penutur yang ingin menikah dengan mitra tutur.

Tindak tutur ekspresif pada data di atas juga ditandai dengan penanda linguistik kepengen yang berarti keinginan, permintaan, permohonan, dan pengharapan penutur. Adapun pengharapan penutur pada data di atas adalah berharap supaya mitra tutur, yakni kekasihnya mau untuk menikah dan menjadi istri penutur. Berdasarkan hal tersebut tindak tutur pada data diatas digolongkan sebagai tindak tutur ekspresif pengharapan.

\section{g. Tindak Tutur Ekpresif Memberi maaf}

Tindak tutur ekspresif memberi maaf merupakan tindak tutur yang bertujuan memberikan maaf kepada mitra tutur. Memberi maaf termasuk kesantunan berbahsa yang harus tetap dilestarikan untuk membentuk karakter anak-anak (Akbar, 2010). Tindak tutur eskpresif memberikan maaf pada plesetan nama Kota di Jawa Tengah bertujuan untuk memberikan maaf kepada mitra tutur. Berikut ini plesetan nama Kota di Jawa Tengah berskpresi memberi maaf.

(9) Kebumen: keburukanmu tak akan kubalas men!!!

Tindak tutur pada data (9) di atas merupakan plesetan nama Kota di Jawa Tengah, yakni kebumen. Kota kebumen pada data di atas diplesetkan menjadi keburukanmu tak akan kubalas men!!! Penutur pada data di atas memberikan maaf kepada mitra tutur. Memohon dan memberikan maaf penting untuk dilakukan supaya terhindar dari konflik (Johari, 2016).

Pemberian maaf yang diberikan oleh penutur kepada mitra tutur dilakukan dengan cara tidak akan membalas berbagai keburukan yang dilakukan oleh mitra tutur. Permohonan dan pemberiaan maaf sebagai representasi kesantunan tindak tutur ekpresif (Saleh \& Baharman, 2012). Hal tersebut dituturkan dengan pernyataan segala keburukan yang dilakukan mitra tutur tidak akan dibalas. Selain itu pada tuturan data di atas menggunakan penggunaan kata men. Kata men pada data di atas merupakan penanda kedekatan penutur dan mitra tutur yang menunjukkan persahabatan atau teman dekat.

\section{h. Tindak Tutur Ekpresif Memuji}

Tindak tutur ekspresif memuji adalah tuturan yang memiliki makna dan tujuan memuji mitra tutur. Eskpresi memuji merupakan salah satu wujud kesantunan dalam berkomunikasi (Dewi et.al, 2018; Kusmanto et.al, 2019).
Realisasi tindak tutur ekpresif memuji pada plesetan nama Kota di Jawa Tengah direalisasikan dengan cara memuji rasa cinta mitra tutur. Berikut ini tuturan plesetan nama Kota berekspresi memuji.

(10) Ambarawa: amat berharga rasa cinta yang kau bawa

Tindak tutur ekspresi memuji pada data (10) di atas merupakan plesetan nama Kota Ambara yang diplesetkan menjadi amat berharga rasa cinta yang kau bawa. Tuturan pada data di atas menunjukkan ekspresi memuji mitra tutur karena rasa cinta yang yang diberikan kepada penutur. Penggunaan ekpresi memuji bertujuan supaya mitra ttutur merasa senang (Saputry, 2016). Plesetan dengan memberikan pujian terhadap rasa cinta pada data di atas dituturkan oleh seorang pemuda kepada seorang pemudi atau kekasihnya.

Tindak tutur eskpresi memuji dalam suatu tuturan menjadi penting, hal ini menunjukkan penutur menghargai mitra tutur. Hal ini sesuai dengan temuan (Handayani et.al, 2016); Zahid dan Hashim (Zahid \& Hashim, 2018) bahwa banyak ditemukan tindak tutur ekpresif memuji yang berfungsi menunjukkan perhatian. Selain itu tuturan ekspresi memuji sebagai wujud kesantunan berkomunikasi antara penutur dan mitra tutur.

\section{i. Tindak Tutur Ekpresif Mengkritik}

Tindak tutur eskpresif mengkritik adalah tuturan yang memiliki makna dan tujuan mengkitik apa yang dilakukan oleh mitra tutur. Tindak tutur eskpresif mengkritik bertujuan untuk memberikan peringatan kepada mitra tutur mengenai suatu hal. Kritik tidak semuanya menimbulkan konflik, kritik dapat dilakukan dengan bahasa yang santun (Jauhari, 2018). Oleh karena itu penting memperhatikan kesantunan berbahasa dalam memberikan kritik, kritik dengan tujuan membangun apabila tidak memperhatikan kesantunan berbahasa bisa jadi menjadi bumerang bagi pengkritik (Kusno, 2015). Tindak tutur ekspresif mengkritik pada plesetan nama Kota di Jawa Tengah direalisasikan cara memperingatkan mitra tutur supaya menepati janji. Berikut ini tuturan plesetan bereskpesi mengkritik.

\section{(11) Boyolali: mbok yao nek janji ojo dilali-lali}

Tuturan pada data (11) di atas merupakan plesetan nama Kota Boyolali yang diplesetkan menjadi mbok yao nek janji ojo dilali-lali. Tuturan tersebut menunjukan mengkritik dengan cara memperingatkan mitra tutur supaya kalau berjanji tidak diingkari. Strategi mengkritik sebaiknya dilakukan apbila mitra tutur memang memiliki kelemahan pada hal yang dikritik artinya bukan mencari-cari kesalahan untuk dikritik (Amelia et.al, 2019). Mengkritik dengan cara memperingatkan merupakan suatu hal yang membangun pada diri mitra tutur.

\section{SIMPULAN}

Berdasarkan hasil dan pembahasan yang telah diuraikan di atas dapat disimpulkan tindak tutur ekpresif pada plesetan nama Kota di Jawa Tengah meliputi ekspresi kesedihan, bahagia, kecewa, mengeluh, meyakinkan, pengharapan, memberi maaf, memuji, dan mengkritik. Tindak tutur 
ekspresif yang paling banyak digunakan adalah eskpresi kesedihan. Hal ini menunjukkan penutur banyak mengalami pengalaman yang membuat sedih.

\section{DAFTAR PUSTAKA}

Akbar, S. (2010). Model Pembelajaran Nilai dan Karakter Berbasis Nilai-nilai Kehidupan di Sekolah Dasar. Jurnal Ilmu Pendidikan, 17(146-54).

Amelia, W., Gani, E., \& Syahrul, R. (2019). Performa Komunikasi Politik dalam Tuturan Persuasif Surya Paloh. LINGUA, XV(1), 36-44.

Defina. (2018). Tindak Tutur Ekspresif pada Anak-anak Saat Bermain Bola di Lapangan. Ranah: Jurnal Kajian Bahasa, 7(1), 69-85.

Devi, L. N., \& Qomaruddin, M. (2017). Prinsip Kerja Sama dalam Bahasa Transaksi Jual Beli Online di Tokopedia.Com. Haluan Sastra Budaya, 1(1), 86-96. https://doi.org/http://dx.doi.org/10.20961/hsb.v1i1.5204

Dewi, R., Suwandi, S., \& Sulistyo, E. T. (2018). Kesantunan Guru dan Siswa Permpuan dalam Pembelajaran Bahasa Indonesia di Sekolah Bilingual. Lingua, 15(2), 147-162. https://doi.org/10.30957/lingua.v15i2

Ekawati, M. (2017). Kesantunan Semu pada Tindak Tutur Ekspresif Marah dalam Bahasa Indonesia. Adabiyyāt, I(1), $1-22$. https://doi.org/https://doi.org/10.14421/ajbs.2017.01101

Febriadina, Z. F., Sumarwati, \& Sumarlam. (2018). Male and Female Student' Politeness in Sragen, Central Java. Humanus, 17(1), 73-83. https://doi.org/10.24036/humanus.v17i1.8429

Handayani, T. K., Megawati, S., \& Malia, L. (2016). Nilainilai karakter dalam Tindak Tutur Ilokusi dalam Buku Wir Besuchen Eine Moschie. Litera, 15(2), 305-318.

Hartati, Y. S. (2018). Tindak tutur asertif dalam gelar Wicara Mata Najwa di Metro TV. Jurnal KATA, 2(2), 296-303. https://doi.org/http://doi.org/10.22216/jk.v2i2.3151

Hendrastuti, R. (2017). Refleksi Sikap dalam Kesantunan Tuturan Cerpen Anak. Sawerigading, 23(2), 229-239. https://doi.org/http://dx.doi.org/10.26499/sawer.v23i2.2 57

Herniti, E., Budiman, A., \& Kusumawati, A. A. (2016). Kesantunan Berbahasa dalam Dakwah Multikultural. Adabiyyat, $\quad X V(1), \quad 36-62$. https://doi.org/https://doi.org/10.14421/ajbs.2016.15103

Jauhari, E. (2018). Alat-alat Kesantunan Kritik dalam Masyarakat Jawa Surabaya: Kajian Pragmatik. Mozaik Humaniora, 18(2), 167-177. https://doi.org/http://dx.doi.org/10.20473/mh.v18i2.109 31

Johari, A. (2016). Manifestasi Kesantunan Melayu dalam Ujaran Memberi dan Meminta Nasihat Manifestation of Malay Politeness in Asking and Giving Advice, 16(June).

Kasenda, S. R. (2018). Tindak Pengancaman dan Penyelamatan Wajah Anies Baswedan dan Basuki "Ahok" Tjahaja Purnama. Jurnal KATA, 2(2), 356-370. https://doi.org/http://doi.org/10.22216/jk.v2i2.3377
Kusmanto, H. (2019). Declarative Illocutionary Acts on The 2019 Election News Discourse: Politopragmatic. Jurnal Kata: Penelitian Tentang Ilmu Bahasa Dan Sastra, 3(1), 34-49. https://doi.org/10.22216/jk.v3i1.3904

Kusmanto, H., Prayitno, H. J., \& Ngalim, A. (2019). Realisasi Tindak Kesantunan Berbahasa pada Komentar Akun Instagram Jokowi: Studi Polittikopragmatik. Jurnal Kandai, 15(1), 47-60. https://doi.org/10.26499/jk.v15i1.1269

Kusno, A. (2015). Pelanggaran Prinsip Kesopanan pada Kasus Delik Penghinaan dan Pencemaran Nama Baik. In Seminar Nasional PRASASTI II "Kajian Pragmatik dalam Berbagai Bidang” (pp. 88-93).

Mahsun, M. S. (2014). Metode Penelitian Bahasa Metode Penelitian Bahasa: Tahapan Strategi Metode dan Tekniknya. Jakarta: Raja Grafindo Persada.

Manaf, N. A. (2011). Kesopan Tindak Tutur Menyuruh dalam Bahasa Indonesia. LITERA, 10(2), 212-225.

Nirmala, V. (2015). Tindak Tutur Ilokusi pada Iklan Komersial Sumatera Ekspress. Kandai, 11(2), 139-150. https://doi.org/10.12345/JK.V11I2.222

Osman, M. W. R., \& Wahab, A. H. (2018). Kesantunan Berbahasa Kaunselor Pelatih dalam Sesi Kaunseling (Language Courteousness Among Counsellor Trainees in Counseling Sessions). GEMA Online ${ }^{\circledR}$ Journal of Language $\quad$ Studies, $18(1), \quad 252-269$. https://doi.org/10.17576/gema-2018-1801-15

Rahayu, Siti, P. (2012). Bentuk dan Fungsi Tuturan Ekspresif dalam Bahasa Francis. Litera, 11(1), 12.

Saleh, M., \& Baharman. (2012). Kesantuanan Tindak Tutur dalam Interkasi Akademik. Jurnal Retorika, 8(2), 123 133. https://doi.org/DOI : 10.26858/retorika.v8i2.3625

Saputry, D. (2016). Strategi Kesantunan Positif dan Negatif dalam Bentuk Tuturan Direktif di Lingkungan STKIP Muhammadiyah Pringsewu Lampung. Jurnal Pesona, 2(1), 149-160.

Sholihatin, E. (2013). Apakah Pisuhan Selalu Bermakna Negatif?: Fungsi Pisuhan dalam Masyarakat Arek dan Masyarakat Mataraman. Mozaik Humaniora, 13(2), 158-167. https://doi.org/http://dx.doi.org/10.20473/mh.v13i2.384 3

Sudaryanto. (2015). Metode dan Aneka Teknik Analisis Bahasa Pengantar Penelitian Wahana Kebudayaan secara Linguistis. Yogyakarta: Sanata Dharma University Press.

Syaifudin, Z. K. (2017). Implikatur dan Kesantunan Positif Tuturan Jokowi dalam Talkshow Mata Najwa dan Implementasinya sebagai Bahan Ajar Bahasa Indonesia di SMK. Jurnal Penelitian Humaniora, 14(1), 55-70. https://doi.org/DOI:

https://doi.org/10.23917/humaniora.v14i1.886

Vida, H. D. (2011). Kontruksi Perempuan dalam Rubrik "CC Single" di Majalah Cita Cinta Edisi Januari-Desember 2019. Jurnal Communication Spectrum, 1(1), 17-40.

Wijana, I. D. P., \& Rohmadi, M. (2009). Analisis Wacana Pragmatik Kajian Teori dan Analisis. Surakarta: Yuma Pustaka. 
Yayuk, R. (2016). Strategi Tindak Tutur Imperatif Bahasa Banjar. Metalingua, 14(2), 225-231. https://doi.org/http://dx.doi.org/10.26499/metalingua.v1 $4 \mathrm{i} 2.198$

Yule, G. (2014). Pragmatik. Yogyakarta: Pustaka Pelajar.

Zahid, I., \& Hashim, N. (2018). Strategi dan Struktur Kesantunan Melayu dalam Kritikan Mentor : Rancangan Realiti Televisyen Strategies and Structures of Malay Politeness in Criticism on Mentor: A Reality Television Programme. GEMA Online Journal of Language Studies, 18(2),

134-153.

https://doi.org/http://doi.org/10.17576/gema-2018-180210134 